\title{
Revisiting prebuilding Dodona
}

\author{
Eleni Vasileiou \\ Ephorate of Antiquities of loannina, Ioannina, GR \\ elvasileiou78@gmail.com
}

\begin{abstract}
The aim of this paper is to put together the currently dispersed information about the occurrence of architectural remains at the archaeological site of Dodona during the so-called prebuilding phase, mainly at the end of the Late Bronze Age-Beginning of Early Iron Age through the reports and diaries of the site's excavators. Moreover, the combination of the architectural remains with the portable finds will lead to suggestions about the site's character during late prehistory. Was it a humble village inhabited by stockbreeders, or a hypaethral sanctuary?
\end{abstract}

KEY WORDS - Dodona; architectural remains; apsidal building; stone-lined postholes; settlement; cult activity

\section{Ponovni pregled predstavbne Dodone}

IZVLEČEK - Namen članka je združiti trenutno razpršene podatke o pojavu arhitekturnih ostankov na arheološkem najdišču Dodona v času t. i. predstavbne faze, kar pomeni med pozno bronasto in zgodnjo železno dobo, in sicer s pomočjo poročil in dnevnikov izkopavalcev najdišča. Poleg tega bo kombinacija arhitekturnih ostankov s prenosnimi najdbami vodila do predlogov o značaju tega najdišča v pozni prazgodovini. Je torej najdišče skromna vas, ki so jo poseljevali živinorejci, ali odprto svetišče?

KLJUČNE BESEDE - Dodona; arhitekturni ostanki; apsidalna stavba; s kamni obložene luknje; naselbina; kultne dejavnosti

The archaeological site of Dodona lies in NW Greece (Epirus) (Fig. 1). There, according to the ancient authors, functioned the oldest Oracle of ancient Greece (for details about the ancient sources see Vasileiou 2019a.99-100). For many years travellers from all over Europe have been trying to locate the exact position of Dodona (Soueref, Vasileiou 2017.181182). At some point it was even written that: "To ascertain the site of Dodona would seem now to require a response from the Oracle itself' (Wordsworth 1881).

The first excavation works at the site were conducted by Constantinos Carapanos, a banker and merchant from Arta (Carapanos 1877; 1878; Manopoulos 2015; Soueref 2015). The excavation lasted from the $6^{\text {th }}$ of September 1875 until February 1876 , and focused on the visible monuments. It covered an area of $c .20000 \mathrm{~m}^{2}$ and reached a depth of $2.5 \mathrm{~m}$. However, Carapanos and his colleagues did not provide us with stratigraphic details and did not manage to reach the virgin soil. Starting in 1920, and continuing for a number of years, the Archaeological Society at Athens (Georgios Sotiriadis, Dimitrios Evangelidis, Sotiris Dakaris, Konstantina Gravani, Chryseis Souli and Amalia Vlachopoulou) and the Ephorate of Antiquities of Ioannina also conducted excavations in the area (Gravani, Souli, Vlachopoulou 2014; Soueref 2019a).

Based on the reports and diaries of the site's excavators, the current paper aims to put together the dis- 
persed data about the existence and nature of the prehistoric architectural remains at Dodona.

The first architectural remains, which can be related to the so-called prebuilding phase of the Sanctuary at Dodona, were unearthed by Evangelidis and Dakaris (1959). They both noted that in the northwestern side of the 'Sacred House' (E1, Temple of Zeus and Dione) (Fig. 2) a series of flattened limestone slabs had been revealed. These were positioned vertically in the virgin soil, having an ellipsoidal curve and following an E-W orientation (Evangelidis, Dakaris 1959.24-30). In close proximity, a stone-lined posthole came to light. The flattened slabs were probably used to prevent damage to the building's wall from rainwater (Evangelidis, Dakaris 1959.26) (Fig. $3)$. The first to question Dakari's interpretation was Andronikos (1966.272). However, the renowned architect Charissis refuted this claim more strongly, and argued that the construction functioned as a drainage channel (Charissis 2010). Additionally, he claimed that if these slabs were part of an edifice the view of the sacred oak tree - laying inside the temple - would have been obscured, while the south entrance to the building would also have been obstructed. However, it is still difficult to choose between the two proposals, namely the function of the slabs as the wall of a building or a drainage channel, and further excavation works are required for a conclusive answer to be provided.

Evangelidis and Dakaris noted that, they discovered an intact prehistoric layer along the west stoa of the 'Sacred House'. In the southwest corner of the building a burned clayish layer came to light, possibly a hearth, $c$. $1.60-1.90 \mathrm{~m}$ in diameter (Evangelidis, Dakaris 1959.65). This contained a significant number of handmade sherds and clay drop-like beads of the Late Bronze age period (Fappas 2010), mixed with ashes and charcoal. Recently, both inside and outside of the southeast corner of the 'Sacred House' some paving (measuring $0.90 \times 2.15 \mathrm{~m}$ ) has been unearthed over the virgin red soil and underneath the Hellenistic peribolos foundation (Velenis, Georgoulas 2008.783; Georgoulas 2016.46; Georgoulas, Skalisti 2017.307-309). Its excavator believes that it is contemporary with the aforementioned hearth.

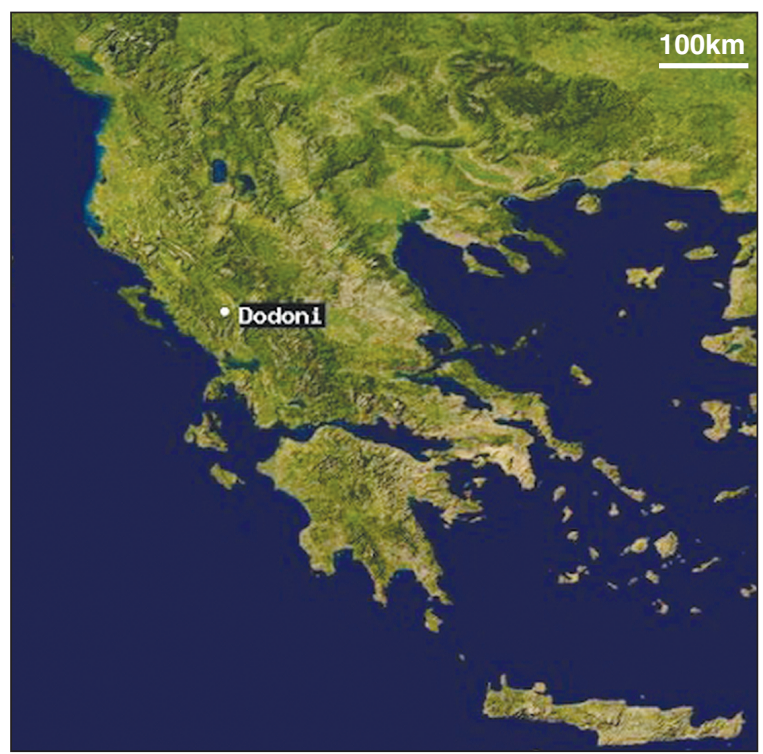

Fig. 1. Map of Greece with the location of Dodona (Google Earth).

While excavating the east part of the Bouleuterion's stoa (E2) (Fig. 2), Dakaris found several black rectangular cavities in the floor, which were assumed to be pits ('bothroi') (Dakaris 1967.39; 1967a.39) (Fig. 4.1). In front of the east entrance of the stoa two circular holes $(a, b)$, probable postholes, were also found. To the south of them, and near the stoa's stylobate, a pit shaped like a figure of eight was un-

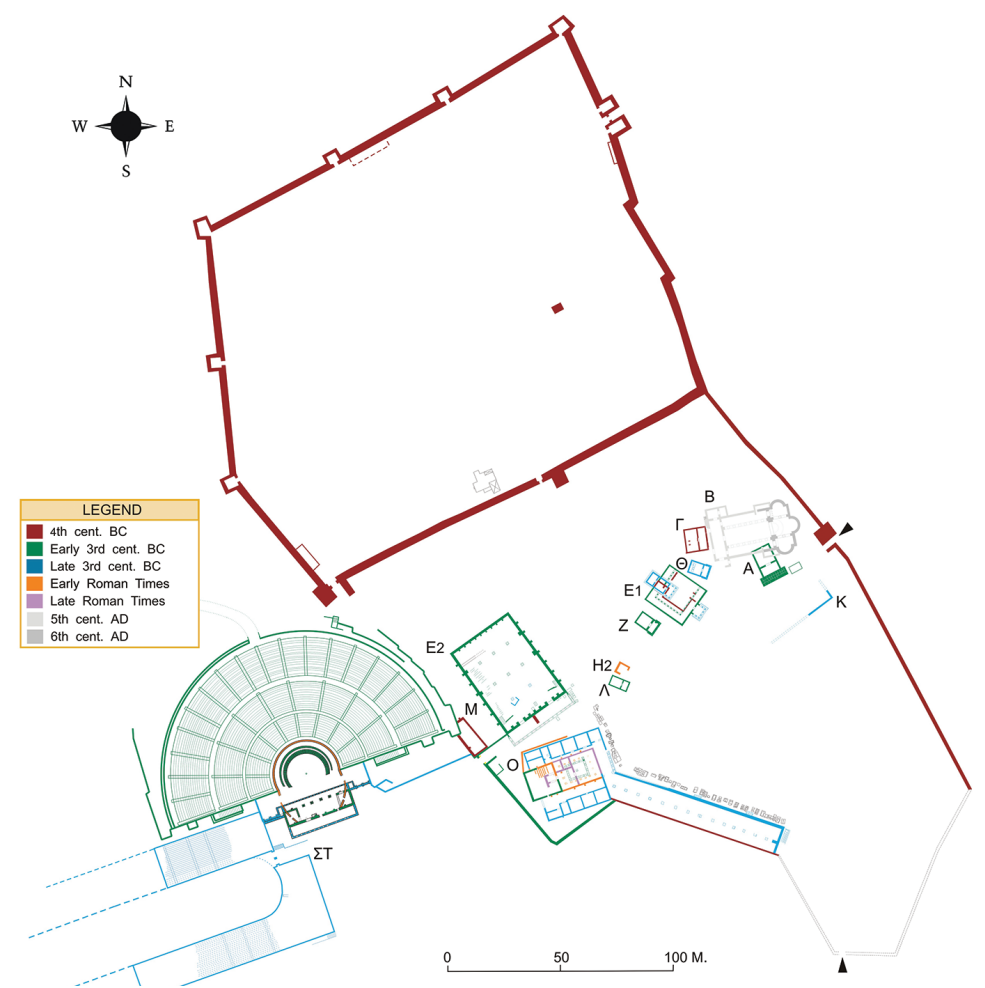

Fig. 2. Plan of the archaeological site of Dodona (Epirus, NW Greece) (C) Ephorate of Antiquities of Ioannina, Hellenic Ministry of Culture and Sports). 
earthed, containing a small number of sherds. Dakaris thought that it could be a small pottery kiln because of the discovery of clay slab fragments and the upper half of a large storage vessel, identified as an eschara and a tholos, respectively (Dakaris 1967. 40-42). However, judging by the fact that no traces of burning have been observed in the vase's interior, the structure could not have functioned as a kiln (Hasaki 2002.221-223, $328-329$ ). From the area adjacent to the stylobate, a number of clay lumps with branch and reed impressions have been collected, suggesting wattling daubed with clay ( $D a$ karis 1967b. 48). Five more postholes surrounded by a stone packing $(\alpha, \beta, \gamma, \delta, \zeta)$ and a vase ( $\varepsilon$, AMI 3715$)$ were found in front of the west entrance of the Bouleuterion on the red virgin soil (Dakaris 1967b). The distance between the axis of the postholes was $1.55 \mathrm{~m}$ (Dakaris 1967.40). It seems that they belonged to a building that extended to the north towards the Bouleuterion's interior and the south towards the exterior of its stoa. No intelligible ground plan has been preserved.

Later, in the Bouleuterion's main hall, the foundations of an apsidal building came to light (Dakaris 1969) (Fig. 4.2). Half of a mattpainted kantharos was found in the east part of the building, while from the foundations a clay biconical spindle whorl dated to the LHIII period was uncovered (Dakaris 1969.

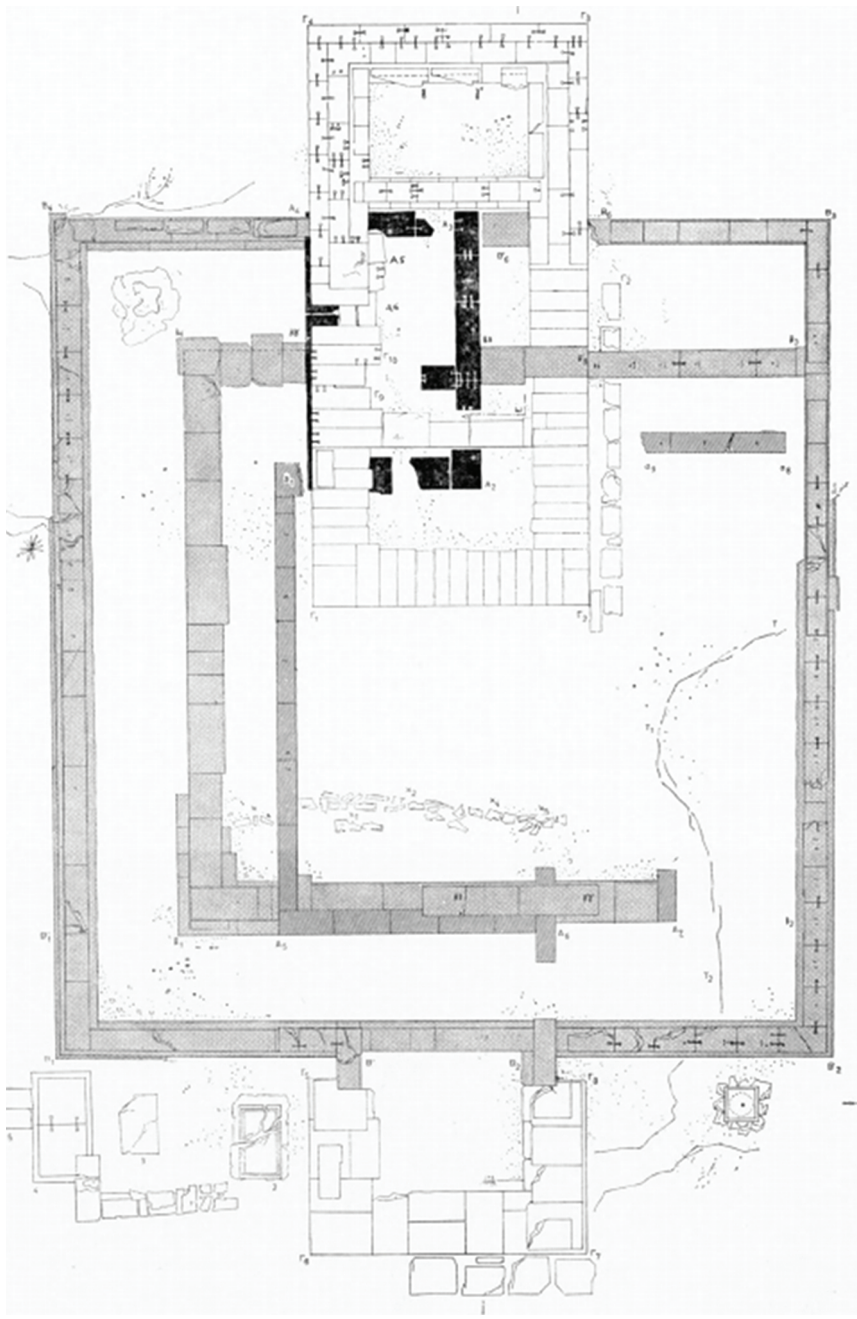

Fig. 3. Plan of the 'Sacred House' (after Evagelidis, Dakaris 1959).
30). According to the excavator's description, the edifice is typical of the Early Iron Age (Dakaris 1969.31) when buildings of different shapes were in use (namely apsidal, oval, elliptical and rectangular) (Mazarakis-Ainian 1997). These buildings would have been covered with perishable materials, while their foundations were made of stone.

In the adjacent Prytaneion (0) (Fig. 2), north of the eastern stoa bases, Dakaris found a circular building made of stone, at a level deeper than one of the bases, with internal and external diameters of 4.20 and 3.25m, respectively (Dakaris 1971a.127, fig.2; 1971c.14-15) (Fig. 4.3). Its fill included handmade and wheel-made sherds, as well as traces of charcoal. Dakaris proposed that the building was contemporaneous with the apsidal one at the Bouleuterion.

In the southwestern corner of room a of the Prytaneion's wing 01 (Fig. 2), the excavators uncovered a circular posthole lined with vertical stones (Daka- ris 1981.7; Gravani 1997.333, footnote 27; 2007. 103, footnote 55) (Fig. 4.4). In trench 23 burned lumps of clay coming from a hut's superstructure and a posthole were found (Souli, Vlachopoulou, Gravani 2000.149, Tab. 91 $\gamma, 92 \alpha$ ) (Fig. 4.5). At the same spot, in trench 33, a significant number of adobe lumps were collected (Souli, Vlachopoulou, Gravani 2004.17). Finally, in the northern edge of the Prytaneion's west stoa, east of base 32, a disturbed layer was revealed and ascribed by the excavator to the Late Bronze-Early Iron Age (Fig. 4.6). This layer can be correlated with the stone relics found deeper in this trench (Georgoulas 2015.783).

Summarizing the data reviewed above, the picture is as follows: a hearth and paving in the 'Sacred House', an apsidal edifice at the Bouleuterion, pits and postholes of a rectangular hut in its stoa, a circular building north of the bases of the eastern stoa of the Prytaneion, postholes and relics of a wall in the Prytaneion (Fig. 4). 




Fig. 4. Plan of the Bouleuterion and the Prytaneion. 1 pits and postholes; 2 apsidal building; 3 circular construction; 4 stone-lined posthole; 5 adobe lumps and posthole; 6 stone relics (Souli, Vlachopoulou, and Gravani 2000).

Building activity is more intense in the western part of the Sanctuary, where the buildings related to the political character of the site were erected, from the $4^{\text {th }}$ century BC onwards. These constructions seem to be part of a small settlement of stockbreeders consisting of huts made of perishable materials (Wardle 1977.177; Dieterle 2007.241; Vasileiou 2008. 141; 2016.42; Luce 2010.25). In Epirus, similar buildings have been found at Vitsa (Zagori) (Vokotopoulou 1982.87-89; 1986), Dourouti (Ioannina basin) (Andreou, Gravani 1997.585- 590), Pogoni (near the Albanian border) (Andréou, Andréou 1999; Andreou 2003), Thesprotiko (Louros valley) (Dakaris 1971b.29, Fig. 48; Konstantaki, Spanodimos 2008. 19, footnote 26), and Aetos (Thyamis valley) (Riginos 2005.574; Metallinou 2012.353). The portable finds consist mainly of everyday vases with thick walls (cooking and storage vessels) (Vasileiou 2015. 44-49) (Fig. 5). Imports from southern and central Greece have also been found, pointing to contacts between the locals and people from these areas. of special interest is the discovery of a large number of handmade high-stemmed kylikes at the Bouleuterion deposit (Dakaris 1967; Wardle 1972.198; 1977.177; Soueref 2001.52; Vasileiou 2015.139-141, 214-215; Yiouni, Vasileiou 2017). Having in mind that none of the deposit's finds seems to be in their original position, probably as a result of levelling in the Hellenistic period for the construction of the Bouleuterion, it can be claimed that their production was part of industrial activity. It is of course very difficult to comment on the organization of the pottery since no production areas or kilns have been discovered. The shape of the hand-made kylix constituted a hybrid type as it combined three different pottery traditions: the Mycenean (shape), the Epirotic (fabric technology of manufacture) and the matt painted ones (decoration) (Yiouni, Vasileiou 2017.410) (Fig. 6). The simultaneous use of kylikes in a number of sites in the Ioannina basin is indicative of organized production exceeding the limits of the household and probably indicating some technical expertise (Soueref 1989.172-173; Vasileiou 2015.214-215). The fact that the kylix came as a result of the fusion of three different traditions, in conjunction with the recovery of their components at Dodona, could lead to the conclusion that this hybrid type was initially produced there (Yiouni, Vasileiou 2017.416). According to the available data, handmade kylikes were restricted chronologically (to the $11^{\text {th }}$ and $10^{\text {th }}$ centuries BC) and contextually (in domestic contexts). Thus, their occurrence at the Bouleuterion deposit consolidates the hypothesis that

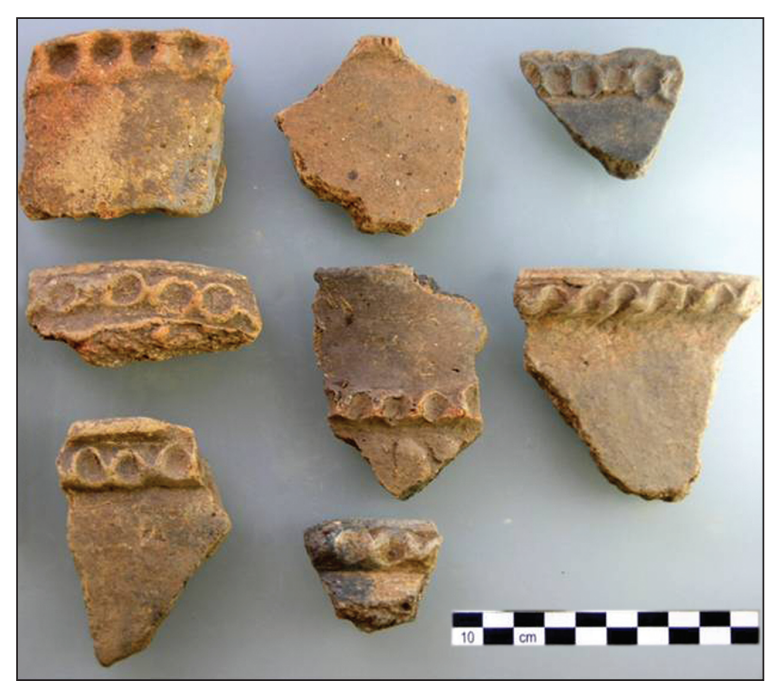

Fig. 5. Handmade pottery from Dodona (photo $E$. Vasileiou). 
there was a settlement dating to the end of the LateBeginning of the Early Iron Age period.

The situation differs in the eastern part of the site. The hearth and paving at the 'Sacred House' can be associated with cultic activity which would have taken place in the open-air (Vasileiou 2015.218; 2016.42; Georgoulas, Skalisti 2017.309 Soueref 2017.398). Regarding the finds relating to the hearth, nothing corroborates its sacred character (sherds of handmade vessels and $c .300$ clay drop-like beads, probably connected to weaving). However, the miniature pottery (Fig. 7) and the non-utilitarian bronze tools and weapons from the adjacent area can support a religious function (Vasileiou 2015.218-219; 2016.42). The miniature vessels could have been filled with offerings to the worshipped deity, and some of these vessels have been classified as ritual vases (Zolotinikova 2019.97). Concerning their chronology, only a few vases have been assigned back to the Early Helladic period, while wheel-made pottery of southern provenance has not been discovered at the 'Sacred House's' deposit. Additionally, a votive character can be attributed to the bulk of the bronze findings (such as knives, axes sometimes bear-

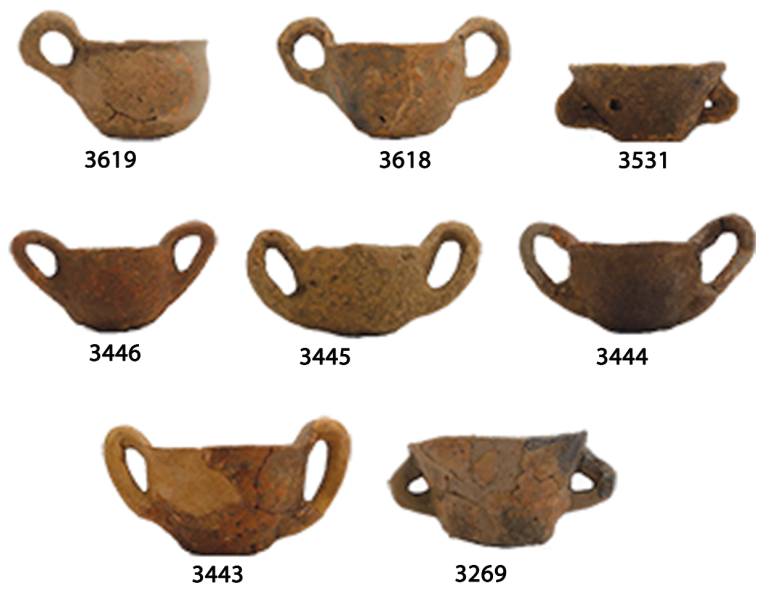

Fig. 7. Handmade miniature vases, Dodona (photo E. Vasileiou).

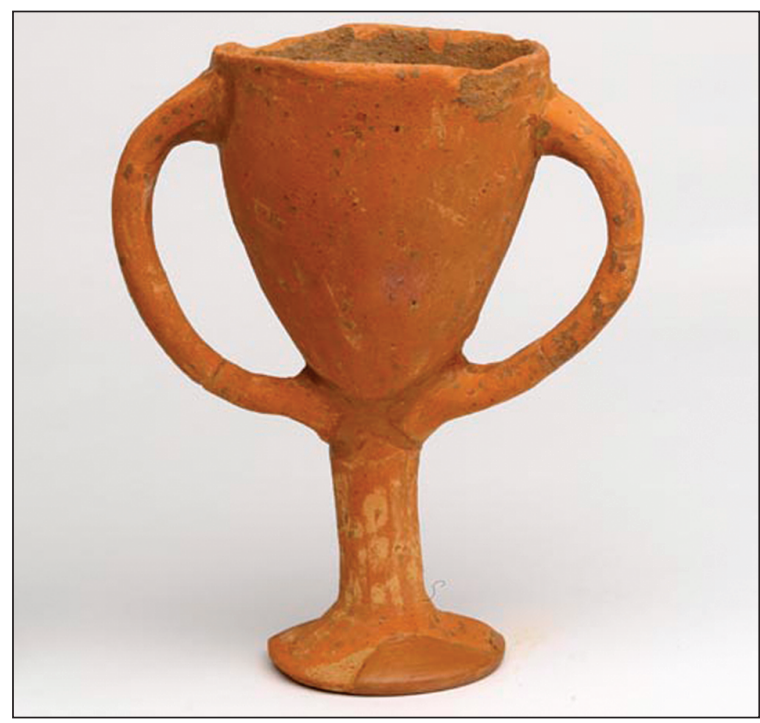

Fig. 6. Handmade high stemmed kylix, Bouleterion deposit, Dodona (AMI 3692) (@ Ephorate of Antiquities of Ioannina, Hellenic Ministry of Culture and Sports).

ing incised and impressed decoration, and spearheads) dating to the Late Helladic-Early Iron Age period, because they were small and sometimes made of a sheet of bronze (Papadopoulos 1976.298-315; Wardle 1977.190-197; Soueref 2001.55-61; 2019b. 55; Vasileiou 2008.139-141; 2015.218-219; 2016. 42). However, it remains unclear if some sort of cult activity took place there (Vasileiou 2019b.113-114).

Consequently, all that can be said with certainty is that there is a clear difference in the use of the east and west parts of the sanctuary of Dodona which can be identified since the prehistoric period. Unfortunately, it is impossible to draw any firm conclusions concerning the nature of the architectural remains of the prebuilding phase at Dodona because of the lack of undisturbed stratigraphic layers, at least for now. However, the pieces of the puzzle are starting to fall into place, and a more complete picture should thus be seen in the years ahead.

\section{References}

Andreou I., Gravani K. 1997. To iero tis Douroutis. Dodoni KST: 581-626. (in Greek)

Andreou H. 2003. Kampila ktismata tis isteris epochis tou Chalkou kai tis proimis epochis tou Sidirou stin koilada tou Gormou Pogoniou. In N. Kyparissi-Apostolika, M. Papakonstantinou (eds.), I Perifereia tou Mikinaikou Kosmou, 2nd Diethnes Simposio, 26-30.09, Lamia 1999. Athens: 117-133. (in Greek)
Andréou E., Andréou I. 1987. Une nécropole tumulaire à Pogoni de l'Épire. In P. Cabanes (ed.), L'Illyrie méridionale et l'Épire dans l'antiquité. Actes du colloque international de Clermont-Ferrand (22-25 octobre 1984). Clermont- Ferrand: 47-49.

1999. Les villages préhistoriques fortifiés de la vallée de Gormos à Pogoni d' Épire. In P. Cabanes (ed.), L'Illyrie méridionale et l'Épire dans la' antiquité - III, Actes 
du IIIe colloque internationale de Chantilly (16-19 Octobre 1996). Paris: 51-56.

Andronikos M. 1966. D. Evangelidis-S. Dakaris, To ieron tis Dodonis. A. Iera Oikia. Gnomon 38: 270-274.

Carapanos, C. 1877. Dodone et ses ruines. Revue Archéologique n.s. 33: 397-405.

1878. Dodone et ses ruines. Vol. 1-2. Paris.

Charissis V. 2010. Dodoni. Architektonika Meletimata. Ekdoseis EHM. Ioannina. (in Greek)

Dakaris S. I. 1967. Anaskafi tou ierou tis Dodonis. Praktika Archaiologikis Etaireias 1967: 33-54. (in Greek)

1967a. Anaskafi tou ierou tis Dodonis. Praktika Achaiologikis Etaireias 1967: 33-54. (in Greek)

1967b. Excavation diary.

1969. Anaskafi tou ierou tis Dodonis. Praktika Archaiologikis Etaireias 1969: 42-59. (in Greek)

1971a. Anaskafi tou ierou tis Dodonis. Praktika Archaiologikis Etaireias 1971: 124-129. (in Greek)

1971b. Cassopaia and the Elean Colonies. Athens. (in Greek)

1971c. Excavation diary.

1981. Anaskafi tou ierou tis Dodonis. Praktika Archaiologikis Etaireias 1981: 67-71. (in Greek)

Dieterle M. 2007. Dodona. Religionsgeschichtliche und historische Untersuchungen zur Entstehung und Entwicklung des Zeus-Heiligtums. Georg Olms Verlag. Hildesheim/Zürich/New York.

Evangelis D., Dakaris S. I. 1959. To ieron tis Dodonis. A' Iera Oikia. Archaiologiki Ephimeris 1959: 1-176.

Fappas I. D. 2010. Apo ti Mesi stin isteri Epochi tou Chalkou: mia oikotechniki drastriotita ston Boiotiko Orchomeno. In A. Philippa-Touchais, G. Touchais, S. Voutsaki, and J. Wright (eds). MESOHELLADIKA: The Greek Mainland in the Middle Bronze Age. Actes du colloque international organisé par l'École française d'Athènes, en collaboration avec l'American School of Classical Studies at Athens et le Netherlands Institute in Athens, Athènes, 8-12 mars 2006. BCH suppl. 52. Ecole française d'Athènes. Athens: 713-719. (in Greek)

Georgoulas G. 2015. Eforeia Archaiotiton Ioanninon. Parakolouthisi ergon. ESPA-Sigchrimatodotoumena erga. 3.
Apokatastasi tou Theatrou kai tis Ditikis Stoas tou Ierou tis Dodonis. A1. Anaskafikes ergasies. Archaeologikon Deltion 70(2015) Chronika B1: 779-784. (in Greek)

2016. I Dodoni kai ta latreutika oikodomimata. In St. Eleutheratou, K. I. Soueref (eds), Dodoni. To Manteio ton ichon. Ekdoseis Mouseio Akropolis. Athina: 46-47. (in Greek)

Georgoulas G., Skalisti E. 2017. Iero Dodonis. Parousiasi neoteron stoicheion apo tis ergasies anadeiksis tou archaiologikou chorou. In SPEIRA, Epistimoniki sinantisi pros timin tis Aggelikas Ntouzougli kai tou Konstantinou Zachou. Praktika. Athens: 307-318. (in Greek)

Gravani K. 1997. Anaglifoi skifoi apo to iero tis Dodonis. In E. Mermigka (ed.), D' Epistimoniki Sinantisi gia tin Ellinistiki keramiki (Mitilini, Martios 1994). Ipourgeio Politismou-Tameio Archaiologikon Poron kai Apallotrioseon kai K' Eforeia Proistorikon kai Klasikon Archaiotiton. Athens: 329-344. (in Greek)

2007. I anaskafiki erevna sto iero tis Dodonis. Ipeirotika Grammata 11: 175-224. (in Greek)

Gravani K., Souli Chr., and Vlachopoulou A. 2014. I anaskafiki erevna sto Iero tis Dodoni. In K. I. Soueref (ed.), Dodoni Diachroniki. Parelthon, Paron ki Mellon tou archaiou theatrou kai tou archaiologikou chorou. Ioannina: 21-42. (in Greek)

Hasaki E. 2002. Ceramic kilns in ancient Greece: technology and organization of ceramic workshops. Unpublished PhD Dissertation. University of Cincinnati. Cincinnati.

Konstantaki A., Spanodimos Ch. 2008. Mnimeia kai archaiologikoi choroi tis Lakkas Souliou tou nomou Prevezas. Ta erga ton anthropon os martires tis diachronikis parousias tou sto choro. Ipeirotikon Koinon 2: 15-43. (in Greek)

Lincoln Ch. 1881. Where was Dodona? Journal of Hellenic Studies 2: 228-232.

Luce J.-M. 2010. Homère, les sanctuaires et le temps. Gaia: revue interdisciplinaire sur la Grèce Archaïque 13: 955.

Manopoulos Gr. 2015. I proti sistimatiki anaskafi tis Dodonis (1875-1876). In G. Papageorgiou, K. Th Petsios (eds.), A' Panipeirotiko Sinedrio Istoria-Logiosini: I Ipeiros kai ta Ioannina apo to 1430 eos to 1913 (Megaro Etaireias Ipeirotikon Meleton, Aithousa K. Katsari, 28 February-3 Martiou 2013). Praktika. Ioannina: 581-613. (in Greek) 
Metallinou G. 2012. LB' Eforeia Proistorikon kai Klasikon Archaiotiton. Aetos Filiaton. In 2000-2010. Apo to Anaskafiko Ergo ton Eforeion Archaiotiton. Ipourgeio Politismou kai Tourismou. Geniki Dieuthinsi Archaiotiton kai Politistikis Klironomias. Athens: 349-354. (in Greek)

Papadopoulos Th. 1976. I epochi tou Chalkou stin Ipeiro. Dodoni 5: 271-338. (in Greek)

Riginos G. 2005. D.D. Aetou. Thesi Skala (oikopedo Apostolou i Micha). Archaiologikon Deltion 60 Chronika B1: 574. (in Greek)

Soueref K. I. 1989. Topiki kai epeisakti keramiki stin Ipeiro kata tin isteri epochi tou chalkou kai proimi epochi sidirou: paratiriseis. Dodona XVIII: 169-175. (in Greek)

2001. Mikinaikes martiries apo tin Ipeiro. Ioannina. Etaireia Ipeirotikon Meleton. (in Greek)

2015. Konstantinos Karapanos (1840-1911) kai Dodoni. Oi aparches tis erevnas. In G. Papageorgiou, K. Th Petsios (eds.), A'Panipeirotiko Sinedrio Istoria-Logiosini: I Ipeiros kai ta Ioannina apo to 1430 eos to 1913 (Megaro Etaireias Ipeirotikon Meleton, Aithousa K. Katsari, 28 February-3 Martiou 2013). Praktika. Ioannina: 581-592. (in Greek)

2017. Epirus and the Mycenaean World: versions and minoentions of immanentia. In M. Fotiadis, R. Laffineur, Y. Lolos, and A. Vlachopoulos (eds.), EГПЕРОГ/ HESPEROS. The Aegean seen from the West. 16 ${ }^{\text {th }}$ International Aegean Conference, Ioannina 18-21.5. 2016. Aegeaum 41. Peeters. Leuven - Liege: 397-400.

2019a. La scoperta e la valorizzazione di Dodona. In C. Malacrino, K. I. Soueref, and L. Vecchio (eds.), Dodonaios. L' Oracolo di Zeus e la Magna Grecia. Museo Archeologico Nazionale Reggio Calabria. MArRC Cataloghi 15. Reggio Calabria: 35-40.

2019b. Il santuario e la topografia. In C. Malacrino, K. I. Soueref, and L. Vecchio (eds.), Dodonaios. L' Oracolo di Zeus e la Magna Grecia. Museo Archeologico Nazionale Reggio Calabria. MArRC Cataloghi 15. Reggio Calabria: 55-71.

Soueref K. I., Vasileiou E. 2017. I diaspora ton archaion tis Dodonis. In K. I. Soueref (ed.), Dodona. The omen's questions. New approaches in the oracular tablets. Ioannina: 181-208. (in Greek)

Souli Chr., Vlachopoulou A., and Gravani K. 2000. Anaskafi Dodonis. Praktika Archaiologikis Etaireias: 145150. (in Greek)

2004. Excavation diary.
Vasileiou E. 2008. I Epochi tou Chalkou. In K. L. Zachos (ed.), To Archaiologiko Mouseio Ioanninon. Ioannina: 43-48. (in Greek)

2015. I cheiropoiiti keramiki tis epochis tou Chalkou kai tis Proimis Epochis tou Sidirou apo tin periochi tis kentrikis Ipeirou: zitimata chronologisis, paragogis kai katanalosis. Unpublished PhD Dissertation. University of Thessaloniki. Thessaloniki. (in Greek)

2016. 0 Dias kai i mantiki velanidia. I latreutiki paradosi. In St. Eleutheratou, K. I. Soueref (eds.), Dodoni. To Manteio ton ichon. Ekdoseis Mouseio Akropolis. Athina: 41-42. (in Greek)

2019a. L' oracolo di Zeus e Dione. In C. Malacrino, K. I. Soueref, and L. Vecchio (eds.), Dodonaios. L' Oracolo di Zeus e la Magna Grecia. Museo Archeologico Nazionale Reggio Calabria. MArRC Cataloghi 15. Reggio Calabria: 99-104.

2019b. I ditti fisi tis latreias tou Dia stin Ipeiro. In K. I. Soueref, A. Gartziou-Tatti (eds.), Gods of Peace and War in the myths of the Mediterranean People. Conference Proceedings. Ioannina 2019: 113-128. (in Greek)

Vokotopoulou I. 1982. I Ipeiros ston 80 kai 70 ai. BC. In Atti del Convegno Internazionale Grecia, Italia e Sicilia nell' VIII e VII sec. A.C., Atene 15-20 Ottobre 1979. Annuario della Scuola Archeologica di Atene e delle Missioni Italiene in Oriente LX (N.S. XLIV): 77-98. (in Greek)

1986. Vitsa: Ta nekrotafeia mias molossikis komis. Athens. (in Greek)

Wardle K. 1972. The Greek Bronze Age West of Pindus. Unpublished PhD Dissertation. University of London. London.

1977. Cultural Groups of the Late Bronze Age and Early Iron Age in North-West Greece. Godišnjak 15: 153-199.

Yiouni P., Vasileiou E. 2017. Production and consumption of kylikes in Late Bronze/Early Iron Age mainland Epirus (Prefecture of Ioannina). In M. Fotiadis, R. Laffineur, Y. Lolos, and A. Vlachopoulos (eds.), EऽПEPOГ/HESPEROS. The Aegean seen from the West. 16 ${ }^{\text {th }}$ International Aegean Conference, Ioannina 18-21.5. 2016. Aegeaum 41. Peeters. Leuven - Liege: 409-418.

Velenis G., Georgoulas G. 2008. Archaiologikos xoros Dodonis. Anaskafiikes ergasies. Iera Oikia. Archaiologiko Deltio 2008 B1 Chronika: 783. (in Greek)

Zolotnikova 0. 2019. The Sanctuary of Zeus in Dodona: Evolution of the religious concept. Journal of Hellenic Religion 12: 85-132. 